\title{
Aktivitas antibakteri ekstrak bawang merah mixture pasta gula pada Staphylococcuc aureus
}

\author{
Tahiruddin Tahiruddin ${ }^{1 *}$, Diah Indriastuti ${ }^{2}$ \\ ${ }^{1,2}$ Program Sarjana Keperawatan, Sekolah Tinggi Ilmu Kesehatan Karya Kesehatan, Indonesia \\ *Coresponding Author: Tahiruddink3@gmail.com
}

\begin{abstract}
Abstrak
Pendahuluan: Terdapat berbagai produk alami yang secara empiris telah digunakan sebagai obat tradisional dalam penyembuhan luka. Bawang merah (Allium cepa) dan gula merupakan bahan alami dalam penyembuhan luka. Tujuan: mengetahui daya hambat ekstrak bawang merah mix pasta gula terhadap pertumbuhan bakteri Staphylococcus aureus secara in vitro. Metode: menggunakan desain eksperimental dengan tiga kali pengulangan. Sampel pada penelitian ini adalah bakteri Staphylococcus aureus, bawang merah, icing sugar, dan castor sugar. Hasil: zona hambat lebih besar pada konsentrasi $100 \%$ ulangan ke-1, yaitu $22,87 \mathrm{~mm}$. Simpulan: Sebagai antibakteri pada penyembuhan luka, bawang merah efektif menghambat mikroba dan gula bekerja secara osmotik, sehingga perlu dikembangkan menjadi topikal dalam penyembuhan luka.
\end{abstract}

Kata kunci: Antibakteri; bawang merah; ekstrak; mixture; pasta gula; Staphylococcus aureus

\section{Antibacterial activities extracts onion pasta sugar mixture on Staphylococcus aureus}

\begin{abstract}
Introduction: There are a variety of natural products that have been empirically used as traditional medicine in wound healing. Shallots (Allium cepa) and sugar are natural ingredients in wound healing. Objective: to determine the inhibition of red onion paste mixture of sugar paste on the growth of Staphylococcus aureus bacteria in vitro. Methods: using an experimental design with three repetitions. The samples in this study were Staphylococcus aureus bacteria, onion, icing sugar, and castor sugar. Results: inhibition zone was greater at the concentration of $100 \%$ of the first replication, which was $22.87 \mathrm{~mm}$. Conclusions: as an antibacterial in wound healing, onion effectively inhibits microbes and sugars from working osmotically, so it needs to be developed to be topical in wound healing.

Keywords: Antibacterial; onion; extrac; mixture; sugar paste; Staphylococcus aureus

How to Cite: Tahiruddin, T \& Indriastuti, D. (2021). Aktivitas antibakteri ekstrak bawang merah mixture pasta gula pada Staphylococcuc aureus. NURSCOPE: Jurnal Penelitian dan Pemikiran IImiah Keperawatan, 7 (1), 22-27

\section{PENDAHULUAN}

Ketika kulit mengalami luka, Staphylococcus Aureus akan masuk melalui luka dan menyebabkan infeksi (Misna \& Diana, 2016). Luka yang terinfeksi sembuh dalam waktu yang lama dan menimbulkan iskemia yang kritis (Agra et al., 2013; Biswas et al., 2010). Terdapat berbagai produk alami yang secara empiris telah digunakan sebagai obat tradisional dalam penyembuhan luka (Zaenal, As'ad, Hadju, \& Agussalim Bukhari, 2016). Bawang merah (Allium cepa) merupakan salah satu tanaman yang secara empiris digunakan oleh masyarakat untuk menyembuhkan luka (Yunanda \& Rinanda, 2017). Selain bawang merah, penggunaan gula pada proses penyembuhan luka berperan sebagai antibakteri dan bekerja secara osmotik (Bhat et al., 2014).
\end{abstract}


Umbi bawang merah mengandung Kmpferol, $\beta$-sitosterol, asam ferulat, asam myritat, dan prostaglandin yang dapat dipercaya sebagai anti diabetes, antioksidan, anti hipertensi, anti trombotik, hipoglikemia, dan anti hiperlipidemia (Shenoy, Patil, Kumar, \& Patil, 2009). Pada metabolit sekunder bawang merah mengandung allisin, aliin, asam fenolat, asam fumarat, asam kafrilat, fosfor, flavonoid, kaempfenol, kuersetin, pektin, saponin, dan lain sebagainya. Pada proses penyembuhan luka, prostaglandin secara alami bekerja sebagai antiinflamasi, sedangkan flavonoid berperan sebagai antiinflamasi dan antimikroba (Yunanda \& Rinanda, 2017).

Penyembuhan luka dan ulkus telah lama menggunakan gula. Schultetus tahun 1679 telah menggunakan gula halus untuk membersihkan luka dan gula telah dipromosikan penggunaannya sebagai terapi luka oleh Zoinin tahun 1714 (Biswas et al., 2010). Gula sebagai wound dressing berfungsi sebagai sumber nutrisi lokal, mengurangi edema inflamasi dan meningkatkan sterilisasi luka, menghasilkan granulasi, dan epitelisasi (Bhat et al., 2014).

Evidence efek ekstrak bawang merah terhadap aktivitas antibakteri telah dilaporkan sebelumnya. Misna dan Diana (2016) melaporkan bahwa ekstrak kulit bawang merah pada konsentrasi $80 \%$ mampu menghambat pertumbuhan bakteri Staphylococcus aureus dengan zona hambat 21,00 $\mathrm{mm}$ (Misna \& Diana, 2016). Yunanda dan Rinanda (2016) juga melaporkan bahwa penyembuhan luka dengan pemberian sediaan topikal ekstrak umbi bawang merah konsentrasi 30\% dan 55\% pada luka sayat kulit mencit strain BalbC berlangsung lebih cepat (Yunanda \& Rinanda, 2017). Shenoy, Patil, Kumar, dan Patil (2009) melaporkan hal sama bahwa ekstrak umbi bawang merah memiliki aktivitas penyembuhan luka yang signifikan (Shenoy et al., 2009). Dipertegas oleh Simaremare (2017) bahwa zona hambat ekstrak umbi bawang merah terhadap bakteri Staphylococcus aureus lebih besar (Simaremare, 2017).

Penelitian efek gula terhadap penyembuhan luka juga telah dilaporkan sebelumnya. Karol dan Allen (2009) melaporkan bahwa gula dengan konsentrasi $195 \mathrm{gr} / 100 \mathrm{~mL}$ air dapat mengurangi air dan menghambat pertumbuhan bakteri (Mathews \& Binnington, 2002). Bhat et al. (2014) juga melaporkan bahwa dari 25 sampel yang diberi perlakuan wound dressing pasta gula setiap hari untuk selama 3 hari, diperoleh hasil dengan tingkat penyembuhan luka lebih cepat (Bhat et al., 2014).

Penyembuhan luka yang buruk memberikan dampak terjadinya infeksi dan nekrosis jaringan hingga kehilangan anggota badan. Oleh sebab itu, maka penulis perlu untuk melakukan penelitian terkait uji daya hambat ekstrak bawang merah mixture pasta gula terhadap pertumbuhan bakteri Staphylococcus aureus secara in vitro.

\section{METODE}

Penelitian ini dilaksanakan di Laboratorium Farmasetika dan Mikrobiologi Politeknik Bina Husada Kendari pada bulan Juli - Oktober 2019. Jenis penelitian ini menggunakan desain eksperimental dengan tiga kali pengulangan. Sampel yang digunakan dalam penelitian ini adalah bakteri Staphylococcus aureus. Selanjutnya bawang merah, icing sugar, dan castor sugar yang diperoleh dari salah satu pedagang di Kota Kendari.

Penelitian ini telah mendapat rekomendasi persetujuan etik dari Komisi Etik Penelitian Ikatan Ahli Kesehatan Masyarakat Indonesia (IAKMI) Pengurus Daerah Provinsi Sulawesi Tenggara Nomor: 004/KEPKIAKMI/VI/2019. Selanjutnya dilakukan uji daya hambat dengan metode sumuran. Zona hambat bakteri diukur dengan menggunakan jangka sorong. Variabel hasil pengukuran dianalisis secara univariat. 


\section{HASIL DAN PEMBAHASAN}

Tabel 1.Daya hambat ekstrak bawang merah mixture pasta gula pada berbagai konsentrasi terhadap Stapilococcus Aureus

\begin{tabular}{ccccc}
\hline \multirow{2}{*}{ Konsetrasi } & \multicolumn{3}{c}{$\begin{array}{c}\text { Zona Hambat ekstrak bawang merah mixture pasta gula } \\
\text { terhadap Stapilococcus Aureus (mm) }\end{array}$} \\
\cline { 2 - 5 } & Ulangan I & Ulangan II & Ulangan III & Rerata \\
\hline $\mathbf{2 5 \%}$ & 14,60 & 14,60 & 14,53 & 14,57 \\
$\mathbf{5 0 \%}$ & 20,83 & 16,00 & 15,50 & 17,44 \\
$\mathbf{7 5 \%}$ & 19,40 & 17,80 & 17,87 & 13,86 \\
$\mathbf{1 0 0 \%}$ & 22,87 & 22,77 & 21,20 & 22,28 \\
Kontrol positif & 0 & 0 & 0 & 0 \\
Kontrol negatif & 0 & 0 & 0 & 0 \\
\hline
\end{tabular}

Berdasarkan tabel 1, zona hambat ekstrak bawang merah mixture pasta gula terhadap Stapilococcus Aureus lebih besar pada konsentrasi $100 \%$ pada ulangan ke-1, yaitu $22,87 \mathrm{~mm}$. Pada ulangan ke-2 dan ke3 juga lebih besar pada konsentrasi $100 \%$, yaitu masing-masing $22,77 \mathrm{~mm}$ dan $21,20 \mathrm{~mm}$. Rerata zona hambat terhadap Stapilococcus Aureus lebih besar pada konsentrasi $100 \%$, yaitu 22,28 mm. Sedangkan pada kontrol positif dan negatif tidak menunjukkan adanya zona hambat $(0 \mathrm{~mm})$.

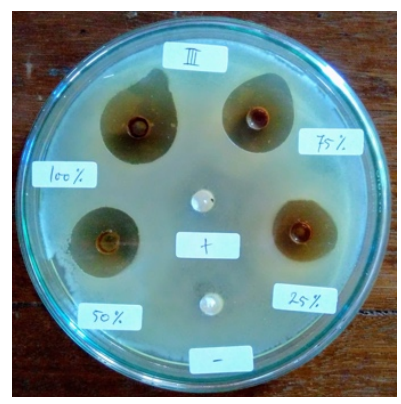

Gambar 1. Zona hambat ekstrak bawang merah mixture pasta gula terhadap Stapilococcus Aureus pada berbagai konsentrasi serta kontrol positif dan negatif

\section{PEMBAHASAN}

Penelitian yang telah dilakukan menujukkan hasil uji antibakteri terhadap bakteri Staphylococcus aureus memiliki zona hambat pada seluruh konsentrasi ekstrak bawang merah mixture pasta gula, yaitu $25 \%$, $50 \%, 75 \%$, dan $100 \%$ (gambar 1). Sedangkan pada kontrol positif dan negatif tidak memiliki zona hambat. Zona hambat yang diperoleh lebih besar pada konsentrasi $100 \%$, yaitu dengan rerata $22,28 \%$. Pada aktivitas ulangan antibakteri seblama 3 kali ulangan, zona hambat terbesar konsentrasi $100 \%$ ulangan ke 2, yaitu $22,77 \mathrm{~mm}$.

Penelitian (Surono, 2013) menemukan adanya daya antibakteri ekstrak umbi lapis bawang merah dengan konsentrasi 40\%, 50\%, 60\%, dan 70\% terhadap bakteri Staphylococcus aureus. Zona hambat terbesar diperoleh pada konsentrasi $80 \%$, yaitu $1,216 \mathrm{~cm}$. Selanjutnya penelitian (Nor, Indriarini, Marten, \& Koamesah, 2018) menunjukkan adanya zona hambat berupa zona bening di sekitar cakram disk yang diukur dengan penggaris. Hasil zona hambat terbesar pada konsentrasi $100 \%$, yaitu $16,00 \mathrm{~mm}$.

Terbentuknya zona hambat menunjukkan bahwa ekstrak bawang merah mixture pasta gula mempunyai sifat antibakteri yang mampu menghambat pertumbuhan bakteri Staphylococcus aureus. Flavonoid pada 
bawang merah berperan sebagai anti-inflamasi dan antimikroba dalam proses penyembuhan luka (Yunanda \& Rinanda, 2017). Selain itu, zona hambat yang terbentuk juga didukung oleh adanya pasta gula yang bekerja menghambat pertumbuhan bakteri dengan tinggi osmotik (Molan \& Rhodes, 2015; Naselli et al., 2017).

Pada penelitian (Biswas et al., 2010) dilaporkan bahwa pada konsentrasi 195 gram gula/100 gram air dapat menghambat proliferasi semua bakteri. Gula membunuh bakteri pada luka dengan cara menarik makrofag ke luka dan juga mempercepat peluruhan jaringan (Bhat et al., 2014).

Berbagai upaya telah dilakukan untuk perawatan luka dengan pengembangan terapi baru baik pada luka akut maupun kronis (Velnar, Bailey, \& Smrkolj, 2009). Antimikroba digunakan dalam perawatan luka bertujuan untuk mencegah dan menghilangkan penyebab infeksi. Kelembaban pada luka dibutukan untuk mendukung penyembuhan luka melalui faktor pertumbuhan sel, sitokin, dan migrasi sel (Leaper et al., 2012).

Prinsip metode perawatan luka modern adalah menjaga kelembaban. Kondisi kering memudahkan terjadinya trauma ulang (Handayani, 2016; Rohmayanti \& Handayani, 2017). Upaya pengembangan terapi baru terhadap perawatan luka terus dikembangkan (Velnar et al., 2009). Gula memiliki efek osmotik (Naselli et al., 2017) sedangkan bawang merah memiliki efek antimikroba (Sharifi-Rad, Mnayer, Tabanelli, Yousaf, \& Vallone, 2016). Hal tersebut dapat mendukung terciptanya kondisi lembab dan meningkatnya efek antimikroba.

\section{SIMPULAN DAN SARAN}

Ekstrak bawang merah mixture pasta gula memilki daya hambat terhambat bakteri Stapilococcus Aureus. Rerata zona hambat terhadap Stapilococcus Aureus lebih besar pada konsentrasi $100 \%$, yaitu 22,28 mm. Perlu adanya upaya pengembangan lebih lanjut tentang topikal yang dapat mempercepat penyembuhan luka.

\section{DAFTAR PUSTAKA}

Agra, I. K. R., Pires, L. L. S., Carvalho, P. S. M., Silva-Filho, E. A., Smaniotto, S., \& Barreto, E. (2013). Evaluation of wound healing and antimicrobial properties of aqueous extract from Bowdichia virgilioides stem barks in mice. Anais Da Academia Brasileira de Ciencias, 85(3), 945-954. http://doi.org/10.1590/S0001-37652013005000049

Bhat, D. R. R., Pai, D. M. V, Hs, D. S. R., Reddy, Sandeep, D., Rai, ... Shivananda, P. (2014). Comparison of Sugar and Honey Dressings in Healing of Chronic \nWounds \n. IOSR Journal of Dental and Medical Sciences (IOSR-JDMS), 13(5), 82-88. Retrieved from http://www.iosrjournals.org/iosrjdms/papers/Vol13-issue5/Version-3/T013538288.pdf

Biswas, A., Bharara, M., Hurst, C., Gruessner, R., Armstrong, D., \& Rilo, H. (2010). Use of sugar on the healing of diabetic ulcers: A review. Journal of Diabetes Science and Technology, 4(5), 1139-1145. http://doi.org/10.1177/193229681000400512

Handayani, L. T. (2016). SStudi Meta Analisis Perawatan Luka Kaki Diabetes Dengan Modern Dressing. The Indonesian Journal Of Health Science, 6(2), 149-159. 
Leaper, D. J., Schultz, G., Carville, K., Fletcher, J., Swanson, T., \& Drake, R. (2012). Extending the TIME concept : what have we learned in the past 10 years ?*. Int Wound J, 9(2), 1-19.

Mathews, K. A., \& Binnington, A. G. (2002). Wound management using sugar. Compend Contin Educ Pract Vet, 24(1), 41-50.

Misna, \& Diana, K. (2016). Aktivitas Antibakteri Ekstrak Kulit Bawang Merah (Allium cepa L.) Terhadap Bakteri Staphylococcus aureus. Galenika Journal of Pharmacy, 2(2), 138-144.

Molan, P., \& Rhodes, T. (2015). Honey: A Biologic Wound Dressing. WOUNDS, 27(6), 141-151.

Naselli, A., Accame, L., Buffa, P., Loy, A., Bandettini, R., Garaventa, A., ... Castagnola, E. (2017). Granulated sugar for adjuvant treatment of surgical wound infection due to multi-drug-resistant pathogens in a child with sarcoma: a case report and literature review. Le Infezioni in Medicina, (4), 358-361.

Nor, T. A., Indriarini, D., Marten, S., \& Koamesah, J. (2018). Uji Aktivitas Antibakteri Ekstrak Etanol Daun Pepaya (Carica papaya L) Terhadap Pertumbuhan Bakteri Escherichia Coli Secara In Vitro. Cendana Medical Journal, 15(5), 327-337.

Rohmayanti, \& Handayani, E. (2017). Modern wound care application in diabetic wound management. International Journal of Research in Medical Sciences, 5(2), 702-706.

Sharifi-Rad, J., Mnayer, D., Tabanelli, G., Yousaf, Z., \& Vallone, L. (2016). Plants of the genus Allium as antibacterial agents: From tradition to pharmacy. Cell. Mol. Biol, 62(9), 57-68. http://doi.org/10.14715/cmb/2016.62.9.10

Shenoy, C., Patil, M. B., Kumar, R., \& Patil, S. (2009). Preliminary phytochemical investigation and wound healing activity of. International Journal of Pharmacy and Pharmaceutical Sciences, 2(2), 167-175.

Simaremare, A. P. R. (2017). Perbedaan Aktivitas Antibakteri Ekstrak Tanaman Bawang Merah (Allium cepa L) Dan Bawang Putih ( Allium sativum L) Pada Berbagai Konsentrasi Terhadap Bakteri Staphylococcus Aureus In Vitro. Nommensen Journal of Medicine, 3(2), 52-27.

Surono, A. S. (2013). Antibakteri ekstrak etanol umbi lapis bawang merah (Allium cepa L.) terhadap pertumbuhan Staphylococcus aureus dan Escherichia coli. Calyptra: Jurnal Ilmiah Mahasiswa Universitas Surabaya, 2(1), 1-15.

Velnar, T., Bailey, T., \& Smrkolj. (2009). The Wound Healing Process : an Overview of the Cellular and Molecular Mechanisms. The Journal of International Medical Research, 37(5), 1528-1542.

Yunanda, V., \& Rinanda, T. (2017). Aktivitas Penyembuhan Luka Sediaan Topikal Ekstrak Bawang Merah (Allium cepa) terhadap Luka Sayat Kulit Mencit (Mus Musculus) Jurnal Veteriner, 17(4), 606-614. http://doi.org/10.19087/jveteriner.2016.17.4.606

Zaenal, As'ad, S., Hadju, V., \& Agussalim Bukhari. (2016). Role of Topical Cream Extract Garlic (Allium sativum) in Wound Healing Fibroblasts Judging from the Strain Wistar Rats with Acute Injury Models. International Journal of Sciences: Basic and Applied Research (IJSBAR), 26(3), 35-47. Retrieved from 
http://gssrr.org/index.php?journal=JournalOfBasicAndApplied 